\title{
A Novel Synthesis of Gold Nanoparticles Supported on Hybrid Polymer/Metal Oxide as Catalysts for p-Chloronitrobenzene Hydrogenation
}

\author{
Cristian H. Campos, ${ }^{1}$ Bruno F. Urbano, ${ }^{1}$ Cecilia C. Torres, ${ }^{2}$ and Joel A. Alderete \\ ${ }^{1}$ Facultad de Ciencias Químicas, Universidad de Concepción, Edmundo Larenas 129, Concepción, Chile \\ ${ }^{2}$ Departamento de Ciencias Químicas, Facultad de Ciencias Exactas, Universidad Andres Bello, Sede Concepción, \\ Autopista Concepción-Talcahuano 7100, Talcahuano, Chile
}

Correspondence should be addressed to Cristian H. Campos; ccampos@udec.cl

Received 1 December 2016; Revised 2 February 2017; Accepted 6 February 2017; Published 22 March 2017

Academic Editor: Renal Backov

Copyright @ 2017 Cristian H. Campos et al. This is an open access article distributed under the Creative Commons Attribution License, which permits unrestricted use, distribution, and reproduction in any medium, provided the original work is properly cited.

This contribution reports a novel preparation of gold nanoparticles on polymer/metal oxide hybrid materials $(\mathrm{Au} / \mathrm{P}[\mathrm{VBTACl}]-$ $\mathrm{M}$ metal: $\mathrm{Al}, \mathrm{Ti}$ or $\mathrm{Zr}$ ) and their use as heterogeneous catalysts in liquid phase hydrogenation of p-chloronitrobenzene. The support was prepared by in situ radical polymerization/sol gel process of (4-vinyl-benzyl)trimethylammonium chloride and 3(trimethoxysilyl)propyl methacrylate in conjunction with metal-alkoxides as metal oxide precursors. The supported catalyst was prepared by an ion exchange process using chloroauric acid (HAuCl4) as gold precursor. The support provided the appropriate environment to induce the spontaneous reduction and deposition of gold nanoparticles. The hybrid material was characterized. TEM and DRUV-vis results indicated that the gold forms spherical metallic nanoparticles and that their mean diameter increases in the sequence, $\mathrm{Au} / \mathrm{P}[\mathrm{VBTACl}]-\mathrm{Zr}>\mathrm{Au} / \mathrm{P}[\mathrm{VBTACl}]-\mathrm{Al}>\mathrm{Au} / \mathrm{P}[\mathrm{VBTACl}]-\mathrm{Ti}$. The reactivity of the Au catalysts toward the $\mathrm{p}-\mathrm{CNB}$ hydrogenation reaction is attributed to the different particle size distributions of gold nanoparticles in the hybrid supports. The kinetic pseudo-first-order constant values for the catalysts in the hydrogenation reaction increases in the order, Au/P[VBTACl]-Al $>\mathrm{Au} / \mathrm{P}[\mathrm{VBTACl}]-\mathrm{Zr}>\mathrm{Au} / \mathrm{P}[\mathrm{VBTACl}]-\mathrm{Ti}$. The selectivity for all the catalytic systems was greater than $99 \%$ toward the chloroaniline target product. Finally the catalyst supported on the hybrid with $\mathrm{Al}$ as metal oxide could be reused at least four times without loss in activity or selectivity for the hydrogenation of $\mathrm{p}-\mathrm{CNB}$ in ethanol as solvent.

\section{Introduction}

Aromatic chloramines are an important building block in the synthesis of many fine chemicals, such as dyes, drugs, herbicides, and pesticides [1-4]. Their conversion has been reported employing heterogeneous metal catalysts as polymer-stabilized colloidal metal clusters [5-9], supported metal catalysts on inorganic solids [5-9], supported metal catalysts on inorganic solids [10-14], and polymer-hybrid supports [15-18]. In the preparation of metal supported catalysts, carriers are first treated with metal precursors followed by reduction into metal nanoparticles using $\mathrm{H} 2$ in thermic treatment or by coupling them with reducing agents in liquid phase such as hydrazine, formic acid, and urea [19-23].
The metals as $\mathrm{Au}, \mathrm{Pt}, \mathrm{Pd}, \mathrm{Ni}$, and $\mathrm{Ir}$ are selective active phases for $-\mathrm{NO}_{2}$ group hydrogenation [10, 21, 24-28], even under mild temperature conditions, especially metallic gold nanoparticles (Au-Nps) [19, 20, 29].

Polycationic-metal oxide hybrid systems have recently been used for anions pollutant remediation since they provide a unique opportunity to include permanent cationic charge in organic functional groups $[30,31]$. These materials arise as an excellent platform for the preparation of metal supported catalysts because they present the main advantage of being metal anion sorbents. The anionic gold precursor, $\mathrm{AuCl}_{4}{ }^{-}$, can exchange anions with the counterion, leaving the gold in intimate contact with the cationic moiety. In this way, recent reports show the spontaneous ability of some materials 
to reduce Au3+ cations to gold nanoparticles (Au-Nps), for example, carbonaceous materials [32], polymers materials [33-35], and metal oxide supports [36-39].

The aim of this research is the use of hybrid materials made from poly[(4-vinylbenzyl)trimethylammonium chloride] $(\mathrm{P}[\mathrm{VBTACl}])$ and three different metal oxides $(\mathrm{Al}, \mathrm{Ti}$, and $\mathrm{Zr}$ ), to produce metal $\mathrm{Au}-\mathrm{Nps}$ supported catalysts for $\mathrm{p}$ chloronitrobenzene ( $\mathrm{p}-\mathrm{CNB})$ liquid phase hydrogenation to obtain the respective $\mathrm{p}$-chloroaniline ( $\mathrm{p}$-CAN). The novelty of this report is the use of this hybrid material as support to provide a simultaneous reduction/deposition of the gold precursor without any external reducing agent and produce highly selective catalytic system for $\mathrm{p}$-CAN production employing hydrogen as reducing agent.

\section{Experimental Section}

2.1. Hybrid Supports Synthesis. The hybrids material synthesis was fully reported in our previous report [40]. The whiteyellow solid hybrid polymer/metal oxide prepared was dried in a vacuum oven at $373 \mathrm{~K}$ for $1 \mathrm{~h}$ and stored in a desiccator under an $\mathrm{N}_{2}$ atmosphere prior to the catalyst synthesis. The material obtained was labeled as $\mathrm{P}[\mathrm{VBTACl}]-\mathrm{M}$ where $\mathrm{M}$ : $\mathrm{Al}, \mathrm{Ti}$, or $\mathrm{Ti}$ corresponds to the metal employed and fully characterized in our previous reports.

2.2. Catalysts Synthesis. The catalysts $(1.0 \mathrm{~g})$ were prepared at $0.5 \% \mathrm{Au}$ mass using the $\mathrm{P}[\mathrm{VBTACl}]-\mathrm{M}$ supports. The appropriate amount of support is placed in a round bottom flask with $50 \mathrm{~mL}$ of water. A solution containing the required amount of the $\mathrm{HAuCl}_{4} \cdot \mathrm{H}_{2} \mathrm{O}$ was aggregated to obtain the desired metal loading and the system was placed in a temperature regulated bath, for $12 \mathrm{~h}$ at $298 \mathrm{~K}$ with $300 \mathrm{rpm}$ of magnetic stirring. During this process, the $\mathrm{pH}$ was monitored and the composites changed color from yellow to purple. The solids were filtered and washed with deionized water until a low constant conductivity was obtained. The metal loading was monitored by ICP, detecting the residual gold in the first and final filtrate solution after mixing with the composite for all catalysts. Finally, the catalysts were dried in a vacuum oven at $373 \mathrm{~K}$ for $1 \mathrm{~h}$ and stored in a desiccator under an $\mathrm{N}_{2}$ atmosphere prior to the catalytic tests. These were labeled as $\mathrm{Au} / \mathrm{P}[\mathrm{VBTACl}]-\mathrm{M}$.

2.3. Characterization. The metal elemental composition was quantitatively (triplicate) monitored by digesting $50 \mathrm{mg}$ of loaded composite in $10 \mathrm{~mL}$ concentrated nitric/hydrochloric (1:3) acid solution using microwave-assisted digestion and the samples were analyzed by inductively coupled plasma atomic emission spectrometer (ICP-AES) Perkin Elmer Elas 6000S instrument. $\mathrm{N}_{2}$-BET surface areas and pore volumes were determined on a Micromeritics ASAP 2010 apparatus at $77 \mathrm{~K}$. UV-vis spectra of diffuse reflectance of solid state (DRUV-vis) were studied in the range of $200-900 \mathrm{~nm}$ on a Varian Cary $3 \mathrm{UV}$-vis spectrophotometer equipped with an area of $150 \mathrm{~mm}$ in diameter covered with poly integration tetrafluoroethylene (PTFE). The dust samples were mounted in a quartz cell, which provided a sample thickness greater than $3 \mathrm{~mm}$ and thus guaranteed "infinite" sample thickness. Electron microscopy were measured using a Transmission Electron Microscope, Philips model CM200 with energy dispersive analyzer and digital camera coupled to a high speed TVIPS FastScan F-114 model of $1024 \times 1024$ pixels. The samples for analysis were prepared by dispersion in ethanol/ $\mathrm{H}_{2} \mathrm{O}(1: 1)$ and deposited on a porous carbon/Cu grid (300 Mesh). Up to 300 individual metal particles were counted for each catalyst and the surface area-weighted mean Au diameter $\left(d_{p}\right)$ was calculated from

$$
d_{p}=\frac{\sum_{i} n_{i} d_{i}^{3}}{\sum_{i} n_{i} d_{i}^{2}},
$$

where $n_{i}$ is the number of particles of diameter $d_{i}$. The size limit for the detection of Au-NPs particles on samples was ca. $1 \mathrm{~nm}$. X-ray photoelectron spectra (XPS) were recorded using an Escalab $200 \mathrm{R}$ spectrometer equipped with a hemispherical analyzer and using nonmonochromatic $\mathrm{Mg}$ $\mathrm{K} \alpha \mathrm{X}$-ray radiation $(h v=1253.6 \mathrm{eV})$. The spectra were fitted to a combination of Gaussian-Lorentzian lines of variable proportion. The $\mathrm{C} 1 \mathrm{~s}$ core-level of adventitious carbon at a binding energy (BE) of $284.8 \mathrm{eV}$ was taken as an internal standard.

2.4. Catalytic Activity. The catalytic assays of p-CNB hydrogenation were performed in a stainless steel, Parr-type batch reactor at a concentration of $0.02 \mathrm{~mol} \mathrm{~L}^{-1}$ of substrate using absolute ethanol as a solvent and stirring at $800 \mathrm{rpm}$ under 20 bar $\mathrm{H}_{2}$ pressure. All further experiments were carried out in the absence of external mass transfer limitations according with our previous experiments and $0.050 \mathrm{~g}$ of catalyst was used for the catalytic measurements. A noninvasive liquid sampling system with in-line filter allowed a controlled removal of aliquots $\left(\leq 0.5 \mathrm{~cm}^{3}\right)$ from the reactor. All the catalytic experiments were made three times (with fresh catalyst every time) and the average values were reported for kinetic data. The reaction samples were analyzed in a GCMS Shimadzu GCMS-QP5050. The conversion level and the CAN's yield were calculated using the following equations:

$$
\begin{aligned}
X(\%) & =\frac{[p-\mathrm{CNB}]_{0}-[p-\mathrm{CNB}]_{t}}{[p-\mathrm{CNB}]_{0}} \cdot 100 \\
Y_{\mathrm{CAN}}(\%) & =\frac{[p-\mathrm{CAN}]_{t}}{[p-\mathrm{CNB}]_{0}} \cdot 100,
\end{aligned}
$$

where $[\mathrm{CNB}]_{0}$ is the $\mathrm{CNB}$ initial concentration and $p-[\mathrm{CNB}]_{t}$ and $p-[\mathrm{CAN}]_{t}$ are the $p$-CNB concentration and $p$-CAN concentration at different time, respectively.

$$
\begin{aligned}
\text { TOF } & \left(\min ^{-1}\right) \\
= & \frac{p \text {-CNB hydrogenated }(\mathrm{mol})}{\text { Surface metallic Au }(\mathrm{mol}) \cdot \text { time }(\mathrm{min})} .
\end{aligned}
$$

The turnover frequency was defined at $20 \%$ of conversion. The values for surface metallic were determinate employing the ICP metal content and metallic dispersion. 


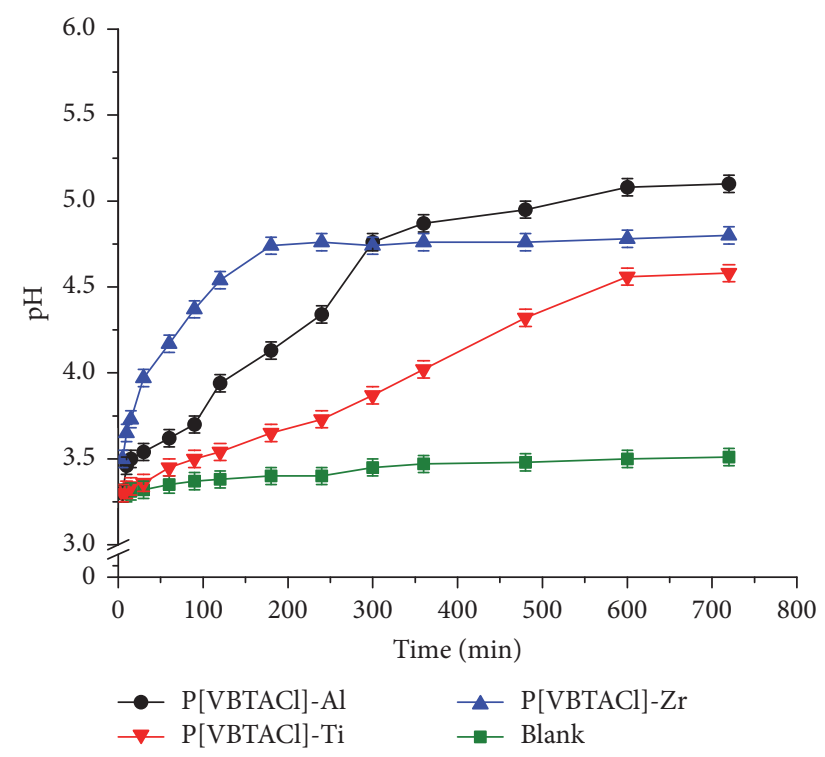

Figure 1: $\mathrm{pH}$ versus time for $\mathrm{P}[\mathrm{VBTACl}] / \mathrm{M}$ catalyst synthesis. Conditions: gold (III) chloride hydrate precursor concentration $6.02 \times 10^{-4} \mathrm{~mol} \mathrm{~L}^{-1}$. Temperature: $298 \mathrm{~K}$ and magnetic agitation: $300 \mathrm{rpm}$. The blank corresponds to the solution of precursor without the support.

\section{Results and Discussion}

3.1. Au Nanoparticles Synthesis and Catalyst Characterization. In the catalysts synthesis, the supports were contacted with metal precursor dissolved in aqueous solution to sorb the active phase on the polymer/metal oxide surface. The $\mathrm{HAuCl}_{4}$ can exchange the chloride ligand with hydroxyl anion providing the formation of mixed chlorohydroxy complexes $\left[\mathrm{AuCl}_{4-x}(\mathrm{OH})_{x}\right]^{-}$as has been reported by Murphy and LaGrange [41]. In other way, P[VBTACl]-M hybrid systems can accumulate gold by ion-exchange process from (1) the poly-cationic quaternary ammonium pending group and (2) metal oxide surface sorption (especially in an acidic range of $\mathrm{pH}$ ) [41]. The $\mathrm{pH}$ measurements could be used to examine the formation of the Au-Nps by spontaneous reduction of metal precursor on the support hybrid materials. Figure 1 shows the plot of $\mathrm{pH}$ versus time during the Au-NPs deposition. During the process we observed the change of solution from yellow (typical for $\mathrm{HAuCl}_{4}$ in solution) to purple as a consequence of the gold nanoparticles surface plasmon band [9, 42, 43]. All the composites show a continuous increase in the $\mathrm{pH}$ of the solution over time. The initial $\mathrm{pH}$ is 3.32 at room temperature for all the composites, though it increases during the course of the preparation to ca. 5.10, 4.58, and 4.80 for P[VBTACl]$\mathrm{Al}, \mathrm{P}[\mathrm{VBTACl}]-\mathrm{Ti}$, and $\mathrm{P}[\mathrm{VBTACl}]-\mathrm{Zr}$, respectively.

At the initial $\mathrm{pH}$, the predominant gold species present in the solution are $\left[\mathrm{AuCl}_{3} \mathrm{OH}\right]^{-}$and $\left[\mathrm{AuCl}_{2}(\mathrm{OH})_{2}\right]^{-}$. The reduction of these gold chlorohydroxy complexes proceeds because they possess a minor redox potential compared to $\left[\mathrm{AuCl}_{4}\right]^{-}$. The sorption of these species could occur in defect sites of the metal oxide surface. These defect sites could provide electronic transfer from the defects on the surface to the $\left[\mathrm{AuCl}_{4-x}(\mathrm{OH})_{x}\right]^{-}$species causing gold spontaneous
TABLE 1: $S_{\text {BET }}$, Au content, and average Au-NPs size by TEM characterization of $\mathrm{Au} / \mathrm{P}[\mathrm{VBTACl}]-\mathrm{M}$ catalysts.

\begin{tabular}{lcccc}
\hline $\mathrm{M}$ & $\begin{array}{c}S_{\mathrm{BET}} \\
\left(\mathrm{m}^{2} \mathrm{~g}^{-1}\right)\end{array}$ & $\begin{array}{c}\text { ICP-AES } \\
(\mathrm{Au} \%)\end{array}$ & $\begin{array}{c}d_{p} \\
(\mathrm{~nm})\end{array}$ & $\begin{array}{c}\text { Dispersion }^{\mathrm{a}} \\
(\%)\end{array}$ \\
\hline $\mathrm{Al}$ & 11 & 0.45 & $5.1 \pm 2.7$ & 19.5 \\
$\mathrm{Ti}$ & 9 & 0.38 & $10.1 \pm 3.8$ & 9.9 \\
$\mathrm{Zr}$ & 10 & 0.42 & $4.5 \pm 2.5$ & 22.2 \\
\hline
\end{tabular}

${ }^{\mathrm{a}}$ Assuming $\mathrm{Au}$ homodispersion and the same metal particle size $\left(d_{p}\right), \mathrm{Au}$ dispersion was calculated using formula $D(\%)=1 / d_{\text {TEM }} \times 100 \%[19]$.

reduction and thus an increase of the $\mathrm{pH}[33,37,38,44]$. This defects are potentials sites for reduction due certainly to the remaining free radicals initiator still trapped into the polymer/metal oxide core as was reported by Féral-Martin et al. [34].

Table 1 displays the ICP-AES analysis for all the Au catalysts synthesized. The Au metal content is very similar to the nominal one. The specific $S_{\mathrm{BET}}$ areas are also summarized in Table 1. These values are similar to the ones of our previous results [40] and they indicate that the supports are not modified upon the impregnation procedure.

Figure 2 shows representative TEM images performed to determine the particle size of Au-NPs on the composites reported here. For the $\mathrm{Au} / \mathrm{P}[\mathrm{VBTACl}]-\mathrm{Zr}$ and $\mathrm{Au} / \mathrm{P}[\mathrm{VBTACl}]-\mathrm{Al}$ catalysts no significant differences in their images are observed. The active phase is randomly dispersed on the composite surface, with metal-particle aggregates particularly visible. Their size distribution is broad but finite ranging from 2.0 up to $10 \mathrm{~nm}$ (Figures 2(a) and 2(c)).

The Au-NPs supported on P[VBTACl]-Ti feature a more random morphology and particle size distribution, composed of bigger crumb-like crystallites, indicative of low dispersion of $\mathrm{Au}$, and the majority of the particles are in the fraction of $8.0-15 \mathrm{~nm}$. On the other hand, solid structures were detected in this catalyst and were attributed to the segregation of the $\mathrm{TiO}_{2}$ phase as was informed in our previous reports [40].

Curiously, P[VBTACl]-Ti was the only one to show a visible inorganic phase segregation after the hybrids synthesis. This behavior could be explained by the fast and spontaneous poly-condensation of the inorganic precursor during the solgel synthesis in comparison to $\mathrm{Zr}$ and $\mathrm{Al}$ metal-alkoxide precursor [45]. The Au-NPs deposited on the support surface showed a preferential deposition around the segregated $\mathrm{TiO}_{2}$ phase as was detected by TEM photographs (Figure 2(b)). On this way, $\mathrm{TiO}_{2}$ could promote a fast reduction of gold ions due to strong binding interactions with oxygen vacancies as was reported by Pan and $\mathrm{Xu}$ [38].

DRUV-vis spectra of the catalysts are shown in Figure 3. For all the $\mathrm{Au} / \mathrm{P}[\mathrm{VBTACl}]-\mathrm{M}$ catalysts, an absorption band between 200 and $300 \mathrm{~nm}$ was observed. The intensity of the absorption band could be attributed to polymeric phase absorption ( $\pi \rightarrow \pi^{*}$ transition from benzene pending groups moieties). For $\mathrm{Au} / \mathrm{P}[\mathrm{VBTACl}]-\mathrm{Ti}$ catalyst, $\mathrm{TiO}_{2}$ species were detected in the range $330-340 \mathrm{~nm}$, indicating the presence of anatase-phase (with particle size $>5.0 \mathrm{~nm}$ ) [46] in agreement 

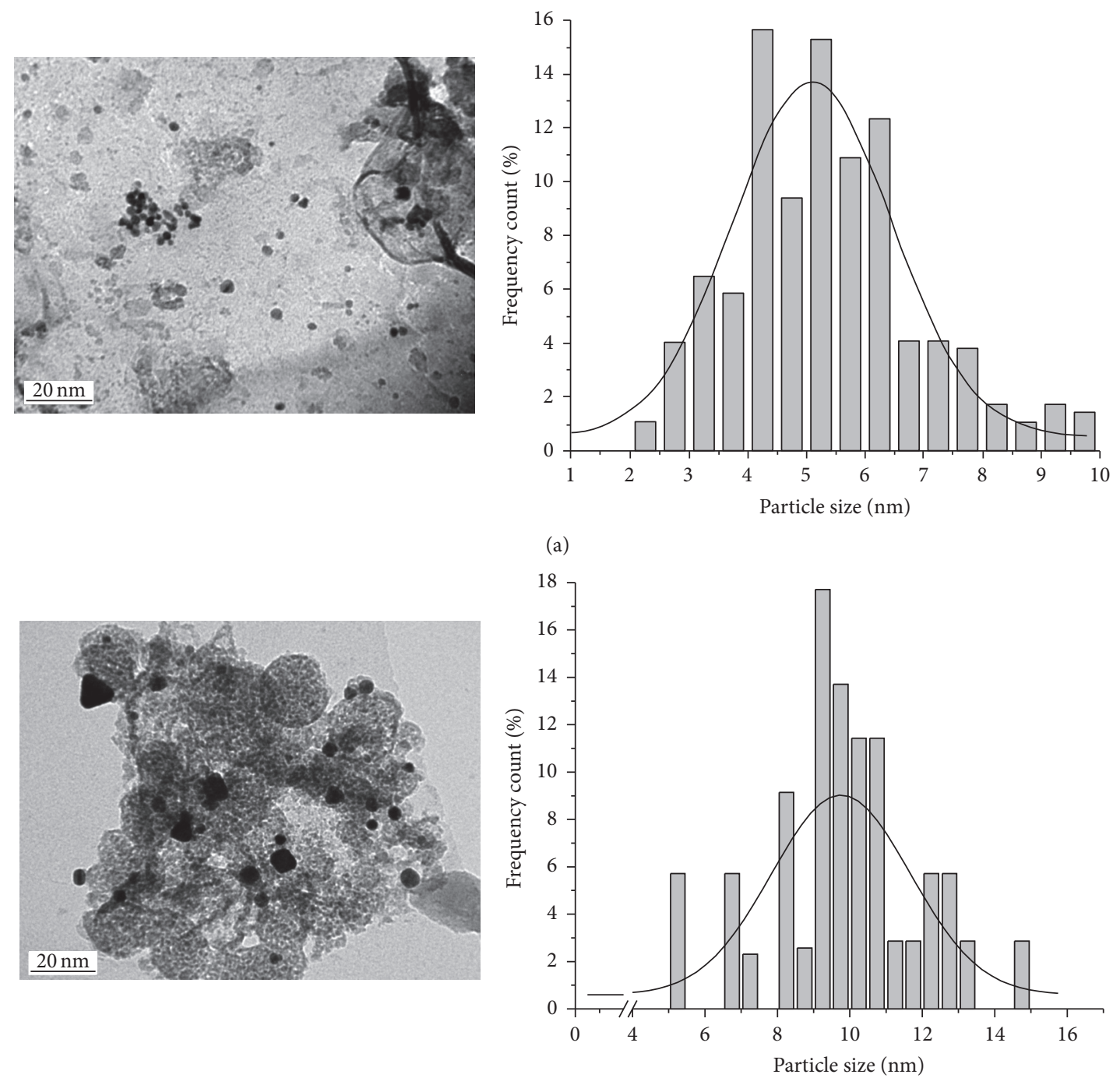

(b)
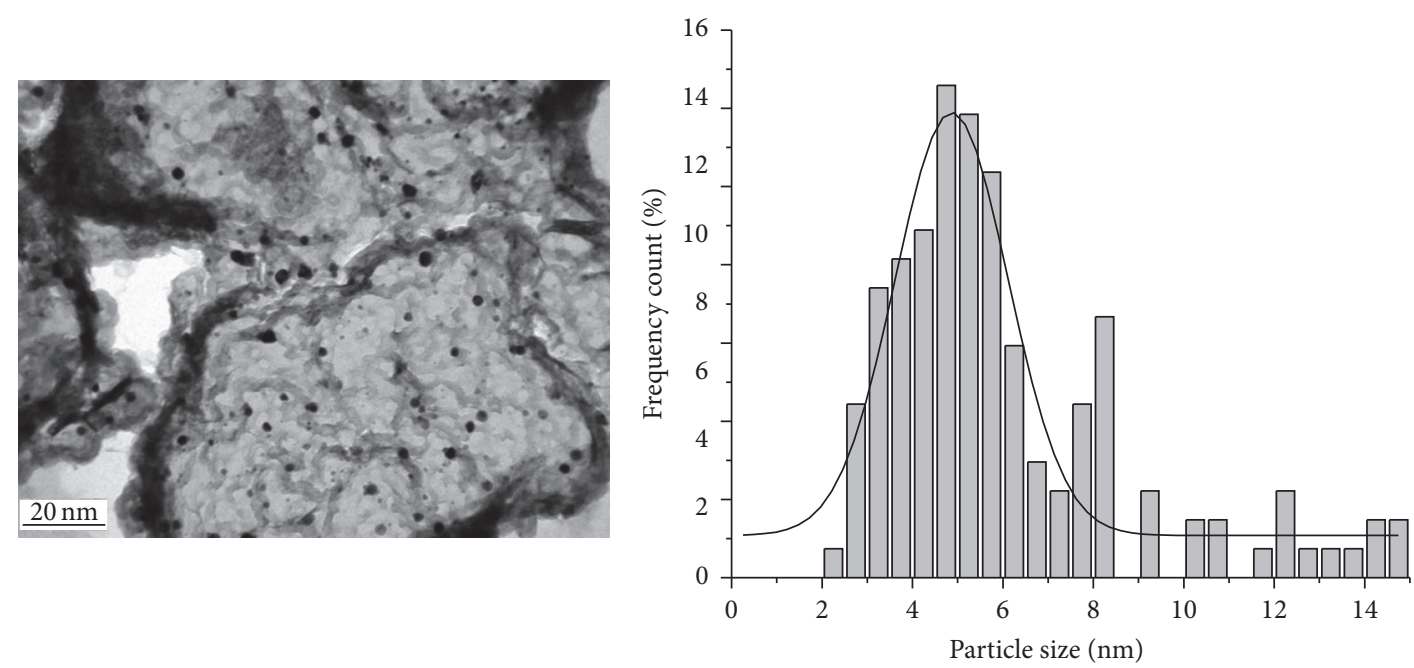

(c)

FIgURE 2: Representative TEM Micrograph and Au nanoparticle size distribution measurements for Au/P[VBTACl]/M catalysts. (a) M: Al; (b) M: Ti; (c) M: Zr. 
TABLE 2: Binding energies (eV) of internal electrons and atomic surface ratio of $\mathrm{Au} / \mathrm{P}[\mathrm{VBTACl}]-\mathrm{M}$ catalysts.

\begin{tabular}{lccccc}
\hline $\mathrm{M}$ & $\begin{array}{c}\mathrm{Mu} 4 \mathrm{f}_{7 / 2} \\
(\mathrm{eV}, 3 \mathrm{~d}\end{array}$ & $\begin{array}{c}\mathrm{N} \mathrm{1s} \\
(\mathrm{eV})\end{array}$ & $\begin{array}{c}\mathrm{Cl} 2 \mathrm{p}_{3 / 2} \\
(\mathrm{eV})\end{array}$ & $\begin{array}{c}\mathrm{Au} / \mathrm{M} \\
\text { sup }\end{array}$ & $\begin{array}{c}\mathrm{N} / \mathrm{Cl} \\
\text { sup }\end{array}$ \\
\hline $\mathrm{Al}$ & 74.6 & 84.2 & 404.0 & 199.1 & 0.0102 \\
$\mathrm{Ti}$ & 458.6 & 84.1 & 403.9 & 199.0 & 0.0059 \\
$\mathrm{Zr}$ & 182.2 & 84.0 & 404.1 & 199.1 & 0.0133 \\
\hline
\end{tabular}

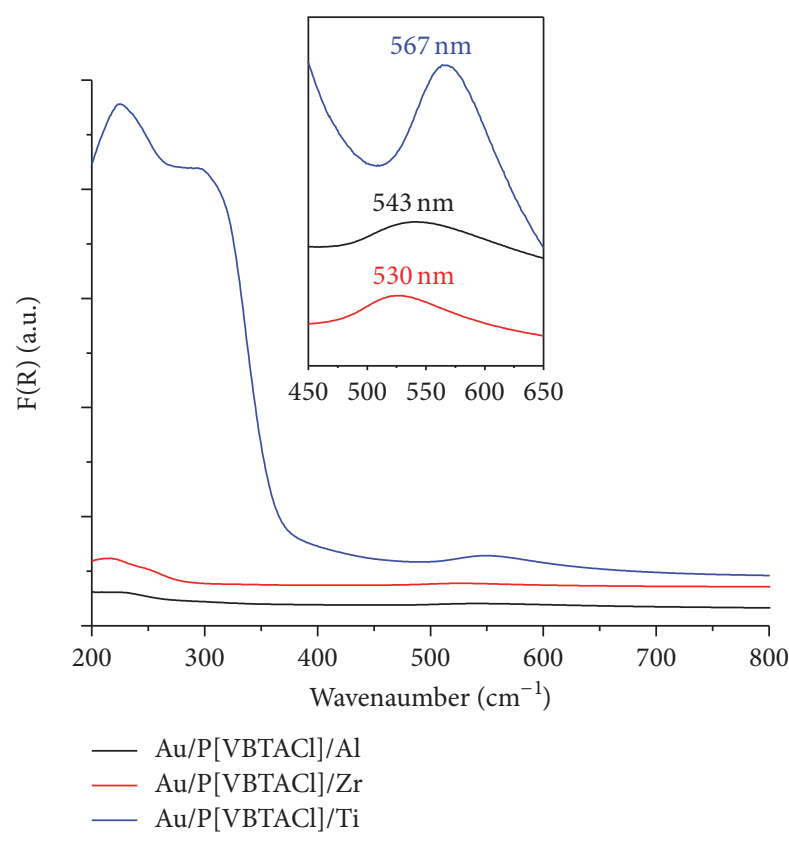

FIgURE 3: DRUV-vis spectra of the Au/P[VBTACl]/M catalyst.

with TEM and XRD characterization previously reported by Campos et al. [40].

The plasmon of Au was observed to be centered between 530 and $560 \mathrm{~nm}$, which indicates that the Au NPs are mostly spherical [47]. The intensity of the plasmon also depends on the particle size [48]. Our results are consistent with a supported metallic $\mathrm{Au}$ for all the catalysts where the differences in characteristic wavelength may be the result of differences in Au particle size as was discussed in TEM characterization (see Table 1).

In order to get a better knowledge on the active gold state, the $\mathrm{Au} / \mathrm{P}[\mathrm{VBTACl}] / \mathrm{M}$ catalysts were characterized by XPS as shown in Table 2. Differences in $\mathrm{Au} 4 \mathrm{f}_{7 / 2}$ binding energy between the samples were observed. The binding energy (BE) of $\mathrm{Au}$ for all catalytic systems showed that $\mathrm{Au} 4 \mathrm{f}_{7 / 2}$ appears at $84.0-84.2 \mathrm{eV}$. This is indicative of the complete reduction of the gold precursor by the hybrid support. This could be attributed to the fact that their $\mathrm{BE}$ is close to that reported for metallic Au nanoparticles [21, 29]. The N 1s BE contribution was detected at $404.0-403.9 \mathrm{eV}$, which is typical for ammonium quaternary groups, while the $\mathrm{Cl} 2 \mathrm{p}_{3 / 2}$ at $199.3 \mathrm{eV}$ corresponds to chloride counter ion in agreement with previous reported results by Deng et al. [49].
TABLE 3: Catalytic properties for the hydrogenation of CNB isomers over Au/P[BVTACl]-M catalysts. Reaction conditions: solvent, $25 \mathrm{~mL}$ absolute ethanol; temperature, $298 \mathrm{~K}$; stirring rate, $800 \mathrm{rpm}$; CNB isomers, $0.02 \mathrm{~mol} \mathrm{~L}^{-1} ; \mathrm{H}_{2}$ pressure, 20 bar.

\begin{tabular}{lccc}
\hline Catalyst & $\begin{array}{c}X^{\mathrm{a}} \\
( \pm 0.2 \%)\end{array}$ & $\begin{array}{c}\text { Yield }^{\mathrm{b}} \\
( \pm 1 \%)\end{array}$ & $\begin{array}{c}\text { TOF } \\
\left(\mathrm{min}^{-1}\right)\end{array}$ \\
\hline $\mathrm{Au} / \mathrm{P}[\mathrm{VBTACl}]-\mathrm{Al}$ & 83.9 & 100 & 252 \\
$\mathrm{Au} / \mathrm{P}[\mathrm{VBTACl}]-\mathrm{Ti}$ & 42.0 & $98^{\mathrm{c}}$ & 49 \\
$\mathrm{Au} / \mathrm{P}[\mathrm{VBTACl}]-\mathrm{Zr}$ & 67.4 & 100 & 99 \\
\hline${ }^{\mathrm{a}}$ Conversion level at & 360 minutes. & ${ }^{\mathrm{b}}$ Yield & mean values. ${ }^{\mathrm{c}} \mathrm{N}-(\mathrm{p}$-chlo- \\
rophenyl)hydroxylamine-intermediary was the only byproduct detected.
\end{tabular}

The $\mathrm{Au} / \mathrm{M}$ atom ratio showed a reasonable value for high $\mathrm{Au}-\mathrm{NPs}$ dispersion for $\mathrm{Au} / \mathrm{P}[\mathrm{VBTACl}]-\mathrm{Al}$ and $\mathrm{Au} /$ $\mathrm{P}[\mathrm{VBTACl}]-\mathrm{Zr}$ catalysts. Furthermore, Au/P[VBTACl]-Ti system showed a lower $\mathrm{Au} / \mathrm{Ti}$ atom ratio, which could be attributed to a decrease in the dispersion of Au active phase and consequently an increase in the Au particle size. This shows good agreement with TEM results (see Figure 2). Finally, all systems showed $\mathrm{N} / \mathrm{Cl}$ atom surface ratio close to 1 , which indicated that the chloride excess was successfully eliminated from catalyst surfaces $\left(\mathrm{N}^{+}\right.$cation $/ \mathrm{Cl}^{-}$anion $)$.

\subsection{Catalytic Hydrogenation Reaction}

3.2.1. P-CNB Hydrogenation. The results obtained for the hydrogenation of $\mathrm{p}-\mathrm{CNB}$ on the Au/P[ClVBTA]-M systems are summarized in Figure 4. The activity of all catalysts changed with the support used. Pseudo-first-order kinetic profiles are observed for $\mathrm{p}-\mathrm{CNB}$ hydrogenation in all cases as shown in Scheme 1. For all catalysts, other side-reactions as dehalogenation, deamination, and/or hydroxylation were not detected. The Au/P[VBTACl]-Al and Au/P[VBTACl]$\mathrm{Zr}$ systems showed considerably higher catalytic activity than $\mathrm{Au} / \mathrm{P}[\mathrm{VBTACl}]-\mathrm{Ti}$ at similar metal loadings. Differences in catalytic activity are related to the Au-NPs size of $\mathrm{Au} / \mathrm{P}[\mathrm{VBTACl}]-\mathrm{Al}$ and $\mathrm{Au} / \mathrm{P}[\mathrm{VBTACl}]-\mathrm{Zr}$ samples as evidenced from TEM and DRUV-vis characterizations. These two systems also showed higher chemoselectivity to -NO2 hydrogenation $(\geq 99 \%)$, producing $\mathrm{p}$-chloroaniline (p-CAN) as main product as shown in Table 3 .

The Au/P[VBTACl]-Ti system showed the lowest catalytic activity and slightly lower yields (96-98\%) for the production of p-CAN where the $\mathrm{N}$-(p-chlorophenyl)hydroxylamineintermediary $(\mathrm{NCPH})$ was the only byproduct detected. The presence of both segregated $\mathrm{TiO} 2$-anatase oxide detected by DRUV-vis and bigger Au-NPs (see Table 1) could cause 


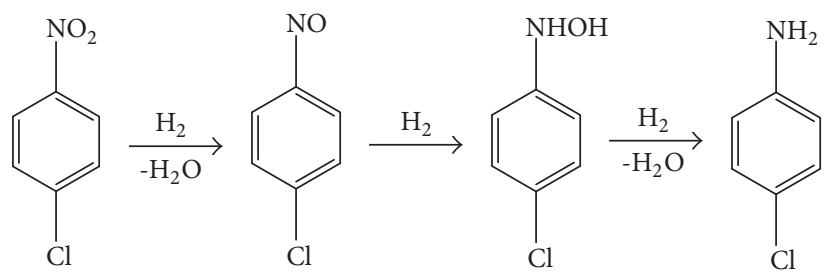

SCHeme 1: Resumed reaction pathway for the hydrogenation of $\mathrm{p}-\mathrm{CNB}$.

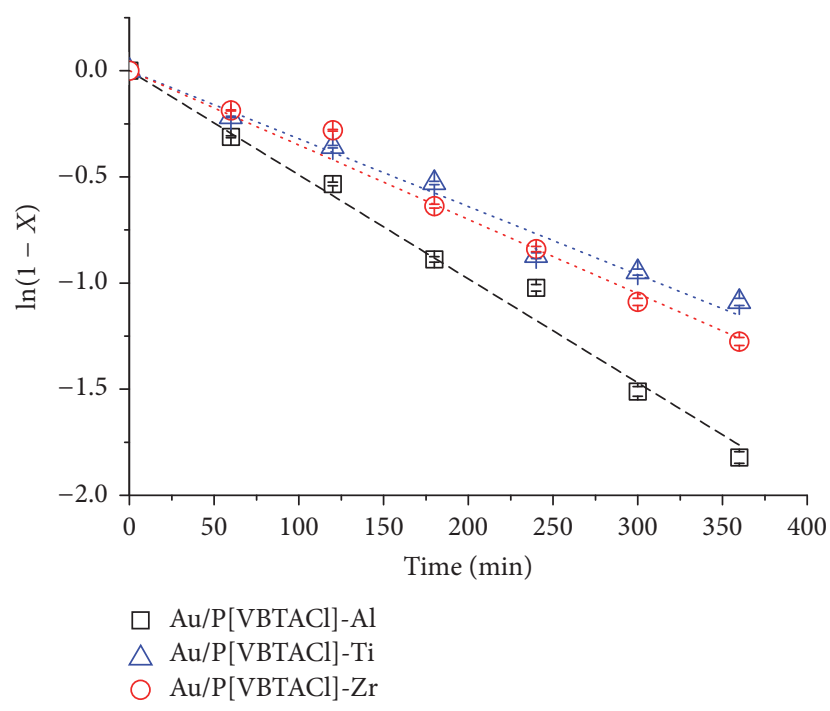

FIgURE 4: Activity curves based on p-CNB conversion for all the synthesized catalysts. Dash line: pseudo-first kinetic model. Reaction conditions: $\mathrm{CNB}$ concentration: $0.02 \mathrm{~mol} \mathrm{~L}^{-1}$, catalyst mass: $0.050 \mathrm{~g}, \mathrm{P}_{\mathrm{H} 2}: 20$ bar, mixing speed: $800 \mathrm{rpm}$, and solvent: absolute ethanol.

the incomplete hydrogenation of the $\mathrm{NCPH}$-intermediary, decreasing yields of p-CAN. [20].

3.2.2. p-CNB Recycling Experiment. The recyclability of the catalysts has been tested in $\mathrm{p}-\mathrm{CNB}$ hydrogenation reaction. The $\mathrm{p}$-CNB isomer showed the best activity-selectivity results of all catalytic reactions studied. Figure 5 shows the recyclability of $\mathrm{Au} / \mathrm{P}[\mathrm{VBTACl}]-\mathrm{M}$ catalysts in terms of activity and selectivity in five successive batches. Figure 5(a) displays the maximum conversion level for all catalysts during the different cycles at 360 minutes. The $\mathrm{Au} / \mathrm{P}[\mathrm{VBTACl}]-\mathrm{Al}$ system used in the first run was recovered from the reaction mixture and reused in five catalytic cycles, showing a nonappreciable decline in its activity and selectivity. After the fourth cycle, total conversion had decreased by $83 \%$. XPS measurements of the $\mathrm{Au} 4 \mathrm{f} 7 / 2$ (Table 4 ) in conjunction with postreaction TEM characterization (see Figure 6(a)) performed on the recovered $\mathrm{Au} / \mathrm{P}[\mathrm{VBTACl}]-\mathrm{Al}$ system after the last run do not show BE changes nor any significative differences in Au-NPs size distribution compared to pristine sample, thus indicating that the chemical and electronic structure of the catalyst were not modified by the catalytic process. The decrease in activity
TABLE 4: ICP-AES, TEM mean Au sizes, XPS data after reaction, and TOF in the last cycle of $\mathrm{Au} / \mathrm{P}[\mathrm{BVTACl}]-\mathrm{M}$ catalysts in the $\mathrm{p}$ $\mathrm{CNB}$ hydrogenation. Reactions conditions: solvent, $25 \mathrm{~mL}$ absolute ethanol; temperature, $298 \mathrm{~K}$; stirring rate, $800 \mathrm{rpm}$; substrate concentration, $0.02 \mathrm{~mol} \mathrm{~L}^{-1} ; \mathrm{H}_{2}$ pressure, 20 bar.

\begin{tabular}{lccccc}
\hline Catalyst & $\begin{array}{c}\text { ICP-AES } \\
(\mathrm{Au} \%)\end{array}$ & $\begin{array}{c}d_{\mathrm{TEM}} \\
(\mathrm{nm})\end{array}$ & $\begin{array}{c}\mathrm{Au} \\
(\mathrm{eV})\end{array}$ & $\begin{array}{c}\mathrm{Au} / \mathrm{M} \\
\text { sup }\end{array}$ & $\begin{array}{c}\mathrm{TOF}^{\mathrm{a}} \\
\left(\mathrm{min}^{-1}\right)\end{array}$ \\
\hline $\mathrm{Au} / \mathrm{P}[\mathrm{VBTACl}]-\mathrm{Al}$ & 0.40 & $5.3 \pm 2.4$ & 84.2 & 0.0040 & 241 \\
$\mathrm{Au} / \mathrm{P}[\mathrm{VBTACl}]-\mathrm{Ti}$ & 0.22 & $17.5 \pm 5.3$ & 83.8 & 0.0008 & 15 \\
$\mathrm{Au} / \mathrm{P}[\mathrm{VBTACl}]-\mathrm{Zr}$ & 0.09 & $4.0 \pm 2.9$ & 84.0 & 0.0013 & $7^{\mathrm{b}}$ \\
\hline
\end{tabular}

${ }^{\mathrm{a}}$ The turnover frequency was defined at $20 \%$ of conversion for the last cycle. The values for surface metallic were determinate employing the ICP metal content and metallic dispersion after the last run. ${ }^{\mathrm{b}} 4 \%$ of conversion level was detected.

in the last run could be attributed to slight leaching of the $\mathrm{Au}$ NPs as was detected by ICP analysis.

The Au/P[VBTACl]-Ti catalyst showed a significant decrease in catalytic activity during the five catalytic cycles. The drop in conversion between the first two batches is 20\%, but on the third cycle there is a drastic drop of $>45 \%$. To gain an insight into the possible mechanism causing the loss in activity and selectivity, the final catalyst has been subjected to ICP and TEM characterization as shown in Table 4.

After the fifth cycle Au Nps increased in size to $13-30 \mathrm{~nm}$. The hydrogenation of nitroarenes catalyzed by gold-catalysts is a structure-sensitive reaction in ethanolic solution as was reported in our previous reports $[19,20,46]$. The presence of bigger Au-NPs crystallites promotes the catalysts deactivation, increasing the incomplete hydrogenation pathways. In this catalyst, $\mathrm{NCPH}$ was the only intermediate detected. Furthermore, a decrease in Au loading in the last run was detected by ICP analysis ( $15 \%)$. Both effects contribute in the decrease of the catalytic activity. Finally, after its use in the last batch, the Au/P[VBTACl]-Ti showed that the BE of Au $4 \mathrm{f} 7 / 2$ was $83.8 \mathrm{eV}$, which is smaller than that measured on the fresh catalyst (BE $84.2 \mathrm{eV})$. This value is typical in electron-rich AuNps that are having strong interactions with $\mathrm{TiO}_{2}$. This effect was also reported in our previous studies of $\mathrm{Au} / \mathrm{TiO}_{2}$-anatase catalysts [20].

Finally, $\mathrm{Au} / \mathrm{P}[\mathrm{VBTACl}]-\mathrm{Zr}$ showed a different behavior during the recycling experiments. This catalyst could not be reused with the same activity. However, in the case of p-CNB, $\mathrm{Au} / \mathrm{P}[\mathrm{VBTACl}]-\mathrm{ZrO} 2$ showed the highest selectivity in all the cycles, which was also observed in the fresh catalyst as shown in Figure 6(c). The ICP analysis showed about 22\% 


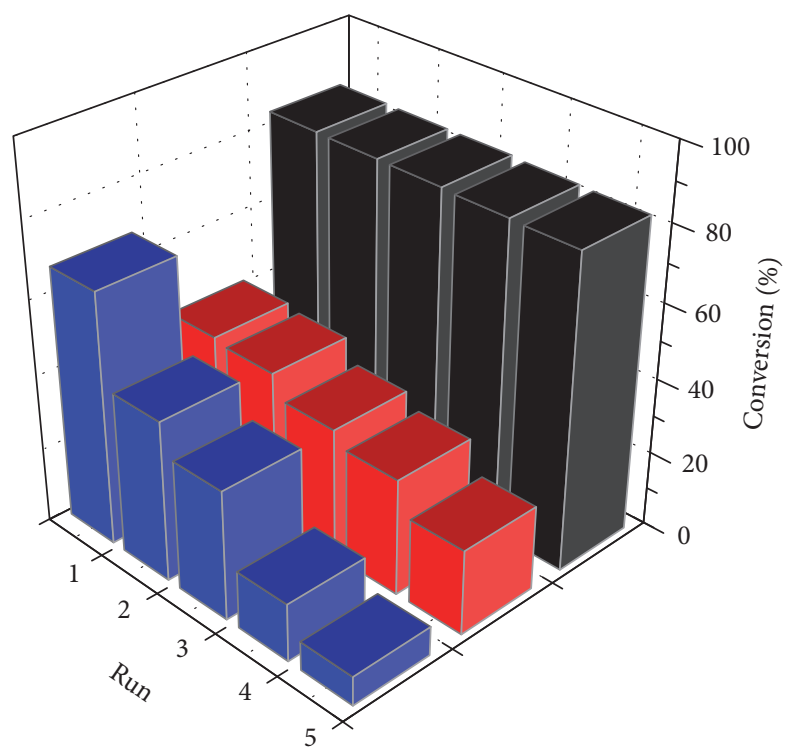

$\mathrm{Au} / \mathrm{P}[\mathrm{VBTACl}]-\mathrm{Al}$
$\mathrm{Au} / \mathrm{P}[\mathrm{VBTACl}]-\mathrm{Ti}$
$\mathrm{Au} / \mathrm{P}[\mathrm{VBTACl}]-\mathrm{Zr}$

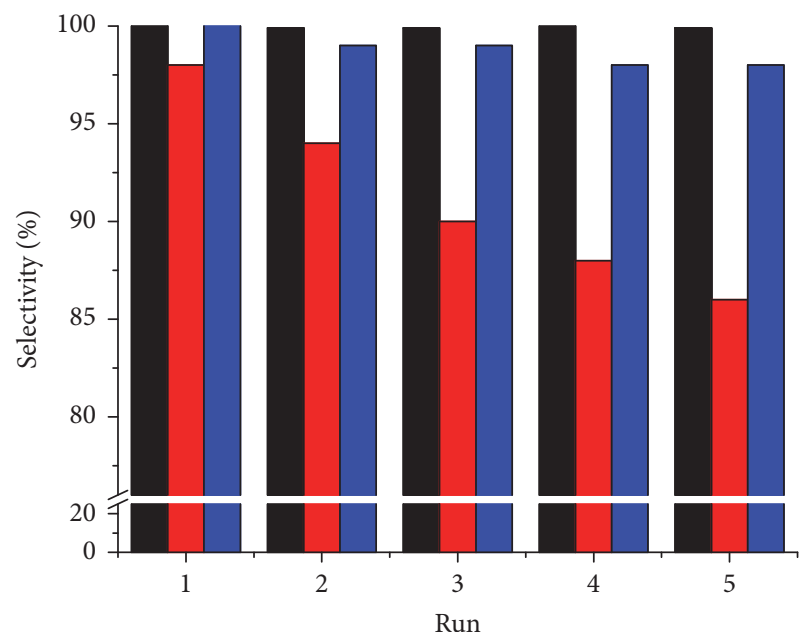

Au/P[VBTACl]-Al $\mathrm{Au} / \mathrm{P}[\mathrm{VBTACl}]-\mathrm{Ti}$ $\mathrm{Au} / \mathrm{P}[\mathrm{VBTACl}]-\mathrm{Zr}$

(a)

(b)

FIGURE 5: Conversion level (a) and selectivity (b) versus number of reaction cycles during the m-CNB hydrogenation over Au/P[VBTACl]/M catalysts. Reaction conditions: p-CNB concentration: $0.02 \mathrm{~mol} \mathrm{~L}^{-1}$, catalyst mass: $0.070 \mathrm{~g}, \mathrm{P}_{\mathrm{H} 2}: 20$ bar, stirring speed: $800 \mathrm{rpm}$, solvent: absolute ethanol. N-(p-chlorophenyl)hydroxylamine-intermediary was the only byproduct detected.

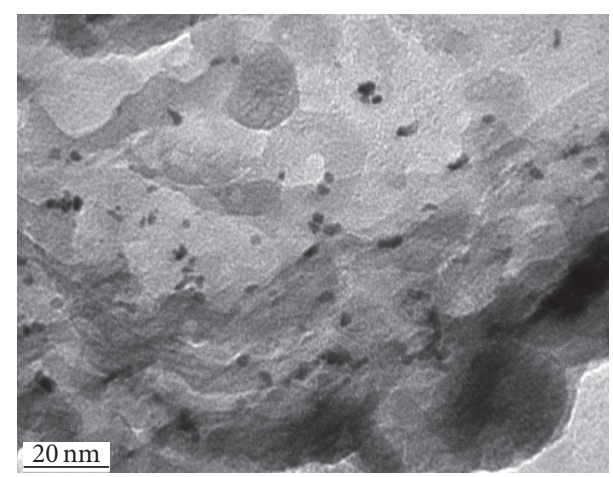

(a)

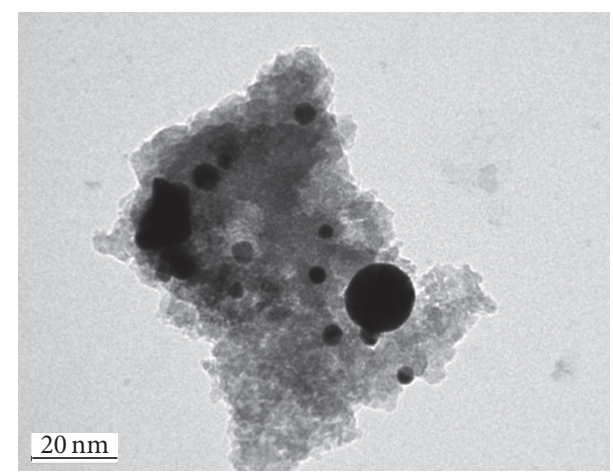

(b)

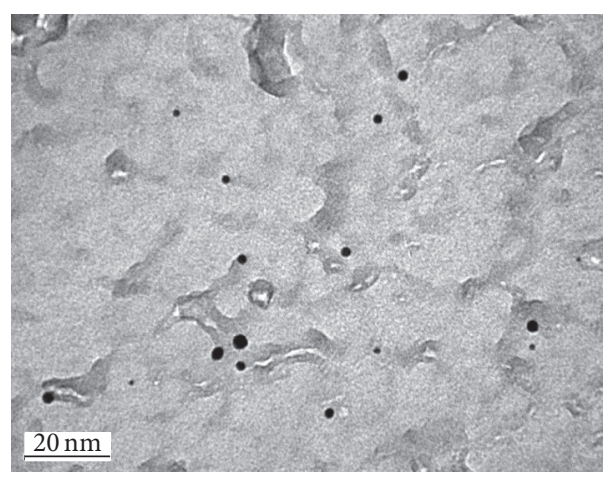

(c)

FIgURE 6: Representative TEM Micrograph for Au/P[VBTACl]/M catalysts after five recycles. (a) M: Al; (b) M: Ti; (c) M: Zr. 
of Au content in the final recovered catalyst; namely, about $78 \%$ of $\mathrm{Au}$ was leached into the reaction solvent, and this is the reason for the decreases in activity. Table 4 shows the TEM measurements for the Au/P[VBTACl]-Zr catalyst after the fifth cycle. The remaining Au nanoparticles did not show any representative aggregation after five cycles.

\section{Conclusions}

Novel Au catalysts were synthesized by an ion-exchange process and in situ spontaneous gold reduction by the polymer-metal oxide hybrid material used as support. The three metal oxides aluminum, titanium, and zirconium in the support structure showed the ability to reduce the gold precursor providing active and chemoselective catalysts for the liquid-phase hydrogenation of p-chloronitrobenzene. The most active and selective catalyst was the gold supported in the hybrid carrier with aluminum oxide as inorganic phase. The catalyst stability when recycling it depends of the metal oxide in the support structure and the maximum conversion levels follow the tendency: aluminum oxide > titanium oxide $>$ zirconium oxide after five cycles. Finally, the gold catalyst supported on polymer/aluminum oxide can be recycled and reused at least five times without loss in activity and chemoselectivity to $-\mathrm{NO}_{2}$ group hydrogenation to produce $\mathrm{p}$-chloroaniline as the main product.

\section{Conflicts of Interest}

The authors declare that they have no conflicts of interest regarding the publication of this paper. The received funding FONDECYT Grants did not lead to any conflicts of interest regarding the publication of this manuscript.

\section{Acknowledgments}

The authors thank CONICYT for the financial support (FONDECYT postdoctoral 3140130 and FONDECYT Initiation 11160468). They also gratefully acknowledge the help of Dr. José Luis G. Fierro of the Instituto de Catálisis y Petroleoquímica (ICP-CSIC), Sustainable Energy and Chemistry Group (Marie Curie 2 Cantoblanco Madrid, Spain), for the XPS analysis.

\section{References}

[1] V. Höller, D. Wegricht, I. Yuranov, L. Kiwi-Minsker, and A. Renken, "Three-phase nitrobenzene hydrogénation over supported glass fiber catalysts: reaction kinetics study," Chemical Engineering and Technology, vol. 23, no. 3, pp. 251-255, 2000.

[2] R. Xu, T. Xie, Y. Zhao, and Y. Li, "Quasi-homogeneous catalytic hydrogenation over monodisperse nickel and cobalt nanoparticles," Nanotechnology, vol. 18, no. 5, Article ID 055602, 2007.

[3] P. Serna and A. Corma, "A residue-free production of biaryls using supported gold nanoparticles," Journal of Catalysis, vol. 315, pp. 41-47, 2014.

[4] P. Serna and A. Corma, "Transforming nano metal nonselective particulates into chemoselective catalysts for hydrogenation of substituted nitrobenzenes," ACS Catalysis, vol. 5, no. 12, pp. 7114-7121, 2015.

[5] H. Cheng, C. Xi, X. Meng, Y. Hao, Y. Yu, and F. Zhao, "Polyethylene glycol-stabilized platinum nanoparticles: the efficient and recyclable catalysts for selective hydrogenation of ochloronitrobenzene to o-chloroaniline," Journal of Colloid and Interface Science, vol. 336, no. 2, pp. 675-678, 2009.

[6] C. Liang, J. Han, K. Shen, L. Wang, D. Zhao, and H. S. Freeman, "Palladium nanoparticle microemulsions: formation and use in catalytic hydrogenation of o-chloronitrobenzene," Chemical Engineering Journal, vol. 165, no. 2, pp. 709-713, 2010.

[7] M. Liu, Q. Wang, Y. Geng et al., "Liquid/liquid interfacial fabrication of thermosensitive and catalytically active $\mathrm{Ag}$ nanoparticle-doped block copolymer composite foam films," Langmuir, vol. 30, no. 34, pp. 10503-10512, 2014.

[8] X. Liu, L. Li, S. Yu et al., "Study on enzymatic degradation of cornstalk in ionic liquid," Catalysis Letters, vol. 144, no. 2, pp. 229-234, 2014.

[9] N. Sahiner, "Soft and flexible hydrogel templates of different sizes and various functionalities for metal nanoparticle preparation and their use in catalysis," Progress in Polymer Science, vol. 38, no. 9, pp. 1329-1356, 2013.

[10] C. Campos, C. Torres, M. Oportus, M. A. Peña, J. L. G. Fierro, and P. Reyes, "Hydrogenation of substituted aromatic nitrobenzenes over $1 \% 1.0 \mathrm{wt} . \% \mathrm{Ir} / \mathrm{ZrO} 2$ catalyst: effect of meta position and catalytic performance," Catalysis Today, vol. 213, pp. 93-100, 2013.

[11] W. Lin, J. Zhao, H. Cheng, X. Li, X. Li, and F. Zhao, "Selective hydrogenation of o-chloronitrobenzene over anatase-ferric oxides supported Ir nanocomposite catalyst," Journal of Colloid and Interface Science, vol. 432, pp. 200-206, 2014.

[12] X. Wang, F. Cárdenas-Lizana, and M. A. Keane, "Toward sustainable chemoselective nitroarene hydrogenation using supported gold as catalyst," ACS Sustainable Chemistry and Engineering, vol. 2, no. 12, pp. 2781-2789, 2014.

[13] X. Wang, N. Perret, J. J. Delgado et al., "Reducible support effects in the gas phase hydrogenation of p-chloronitrobenzene over gold," Journal of Physical Chemistry C, vol. 117, no. 2, pp. 9941005, 2013.

[14] E. H. Boymans, P. T. Witte, and D. Vogt, "A study on the selective hydrogenation of nitroaromatics to $\mathrm{N}$-arylhydroxylamines using a supported Pt nanoparticle catalyst," Catalysis Science \& Technology, vol. 5, no. 1, pp. 176-183, 2015.

[15] L. Hao, Y. Zhao, B. Yu et al., "Polyurea-supported metal nanocatalysts: synthesis, characterization and application in selective hydrogenation of o-chloronitrobenzene," Journal of Colloid and Interface Science, vol. 424, pp. 44-48, 2014.

[16] Y. Mei, Y. Lu, F. Polzer, M. Ballauff, and M. Drechsler, "Catalytic activity of palladium nanoparticles encapsulated in spherical poly electrolyte brushes and core-shell microgels," Chemistry of Materials, vol. 19, no. 5, pp. 1062-1069, 2007.

[17] G. Sharma, Y. Mei, Y. Lu et al., "Spherical polyelectrolyte brushes as carriers for platinum nanoparticles in heterogeneous hydrogenation reactions," Journal of Catalysis, vol. 246, no. 1, pp. $10-14,2007$.

[18] H. Zhang and X.-L. Yang, "Magnetic polymer microsphere stabilized gold nanocolloids as a facilely recoverable catalyst," Chinese Journal of Polymer Science, vol. 29, no. 3, pp. 342-351, 2011.

[19] C. H. Campos, M. Jofré, C. C. Torres, B. Pawelec, J. L. G. Fierro, and P. Reyes, "Chemoselective hydrogenation of $\mathrm{o}^{-}, \mathrm{p}$ - and $\mathrm{m}$-chloronitrobenzene at ambient temperature on $\mathrm{Au} / \mathrm{Fe} 2 \mathrm{O} 3$ 
catalysts," Applied Catalysis A: General, vol. 482, pp. 127-136, 2014.

[20] C. Torres, C. Campos, J. L. G. Fierro, M. Oportus, and P. Reyes, "Nitrobenzene hydrogenation on $\mathrm{Au} / \mathrm{TiO}_{2}$ and $\mathrm{Au} / \mathrm{SiO}_{2}$ catalyst: synthesis, characterization and catalytic activity," Catalysis Letters, vol. 143, no. 8, pp. 763-771, 2013.

[21] C. H. Campos, E. Rosenberg, J. L. G. Fierro et al., "Hydrogenation of nitro-compounds over rhodium catalysts supported on poly[acrylic acid]/Al2O3 composites," Applied Catalysis A: General, vol. 489, no. 1, pp. 280-291, 2015.

[22] H. Pan, X. Li, Y. Yu et al., "Pt nanoparticles entrapped in mesoporous metal-organic frameworks MIL-101 as an efficient catalyst for liquid-phase hydrogenation of benzaldehydes and nitrobenzenes," Journal of Molecular Catalysis A: Chemical, vol. 399, pp. 1-9, 2015.

[23] D. Dutta and D. K. Dutta, "Selective and efficient hydrogenation of halonitrobenzene catalyzed by clay supported Nionanoparticles," Applied Catalysis A: General, vol. 487, pp. 158164, 2014

[24] A. B. Dongil, C. Rivera-Cárcamo, L. Pastor-Pérez, A. SepúlvedaEscribano, and P. Reyes, "Ir supported over carbon materials for the selective hydrogenation of chloronitrobenzenes," Catalysis Today, vol. 249, article no. 9323, pp. 72-78, 2015.

[25] J. Xiong, J. Chen, and J. Zhang, "Liquid-phase hydrogenation of o-chloronitrobenzene over supported nickel catalysts," Catalysis Communications, vol. 8, no. 3, pp. 345-350, 2007.

[26] S. Ichikawa, T. Seki, and T. Ikariya, "Chemoselective hydrogenation of halonitroaromatics over platinum on carbon as catalyst in supercritical carbon dioxide," Advanced Synthesis and Catalysis, vol. 356, no. 11-12, pp. 2643-2652, 2014.

[27] H. Cheng, X. Meng, L. He, W. Lin, and F. Zhao, "Supported polyethylene glycol stabilized platinum nanoparticles for chemoselective hydrogenation of halonitrobenzenes in $\mathrm{scCO}_{2}$," Journal of Colloid and Interface Science, vol. 415, pp. 1-6, 2014.

[28] F. Bauer, H.-J. Gläsel, U. Decker et al., “Trialkoxysilane grafting onto nanoparticles for the preparation of clear coat polyacrylate systems with excellent scratch performance," Progress in Organic Coatings, vol. 47, no. 2, pp. 147-153, 2003.

[29] D. He, H. Shi, Y. Wu, and B. Xu, "Synthesis of chloroanilines: selective hydrogenation of the nitro in chloronitrobenzenes over zirconia-supported gold catalyst," Green Chemistry, vol. 9, no. 8, pp. 849-851, 2007.

[30] J. Pérez, L. Toledo, C. H. Campos, B. L. Rivas, J. Yañez, and B. F. Urbano, "Organic-inorganic interpenetrated hybrids based on cationic polymer and hydrous zirconium oxide for arsenate and arsenite removal," Chemical Engineering Journal, vol. 287, pp. 744-754, 2016.

[31] J. Pérez, L. Toledo, C. H. Campos, J. Yañez, B. L. Rivas, and B. F. Urbano, "Arsenic sorption onto an aluminum oxyhydroxide-poly[(4-vinylbenzyl)trimethylammonium chloride] hybrid sorbent," RSC Advances, vol. 6, no. 34, pp. 2837928387, 2016

[32] M. A. Raj and S. A. John, "Assembly of gold nanoparticles on graphene film via electroless deposition: spontaneous reduction of $\mathrm{Au}^{3+}$ ions by graphene film," RSC Advances, vol. 5, no. 7, pp. 4964-4971, 2015.

[33] N. L. Lala, T. C. Deivaraj, and J. Y. Lee, "Auto-deposition of gold on chemically modified polystyrene beads," Colloids and Surfaces A: Physicochemical and Engineering Aspects, vol. 269, no. 1-3, pp. 119-124, 2005.

[34] C. Féral-Martin, M. Birot, H. Deleuze, A. Desforges, and R. Backov, "Integrative chemistry toward the first spontaneous generation of gold nanoparticles within macrocellular polyHIPE supports (Au@polyHIPE) and their application to eosin reduction," Reactive and Functional Polymers, vol. 67, no. 10, pp. 1072-1082, 2007.

[35] T. M. Kabomo and M. S. Scurrell, "Synthesis of gold-polyaniline nanocomposites by complexation," Polymers for Advanced Technologies, vol. 27, no. 9, pp. 1195-1203, 2016.

[36] E. Nativ-Roth, K. Rechav, and Z. Porat, "Deposition of gold and silver on porous silicon and inside the pores," Thin Solid Films, vol. 603, pp. 88-96, 2016.

[37] S. Mohammadnejad, J. L. Provis, and J. S. J. van Deventer, "Reduction of gold(III) chloride to gold(0) on silicate surfaces," Journal of Colloid and Interface Science, vol. 389, no. 1, pp. 252259, 2013.

[38] X. Pan and Y. Xu, "Fast and spontaneous reduction of gold ions over oxygen-vacancy-rich $\mathrm{TiO} 2$ : a novel strategy to design defect-based composite photocatalyst," Applied Catalysis A: General, vol. 459, pp. 34-40, 2013.

[39] B. C. Prolo Massola, N. M. Pereira De Souza, F. F. F. Stachack et al., "Au- $\mathrm{ZnO}$ prepared by simple in situ reduction and spontaneous of gold nanoparticles on the surface of the layered zinc hydroxide using a novel one-pot method," Materials Chemistry and Physics, vol. 167, pp. 152-159, 2015.

[40] C. H. Campos, B. F. Urbano, and B. L. Rivas, "Hybrid composites from poly[(4-vinylbenzyl)trimethylammonium chloride]metal oxide using simultaneous radical polymerization/sol-gel synthesis," Materials Letters, vol. 131, pp. 198-202, 2014.

[41] P. J. Murphy and M. S. LaGrange, "Raman spectroscopy of gold chloro-hydroxy speciation in fluids at ambient temperature and pressure: a re-evaluation of the effects of $\mathrm{pH}$ and chloride concentration," Geochimica et Cosmochimica Acta, vol. 62, no. 21-22, pp. 3515-3526, 1998.

[42] D. T. Nguyen, D.-J. Kim, and K.-S. Kim, "Controlled synthesis and biomolecular probe application of gold nanoparticles," Micron, vol. 42, no. 3, pp. 207-227, 2011.

[43] H. Wu, X. Ji, L. Zhao, S. Yang, R. Xie, and W. Yang, "Shape evolution of citrate capped gold nanoparticles in seeding approach," Colloids and Surfaces A: Physicochemical and Engineering Aspects, vol. 415, pp. 174-179, 2012.

[44] H. He, B. Adzima, M. Zhong et al., "Multifunctional photocrosslinked polymeric ionic hydrogel films," Polymer Chemistry, vol. 5, no. 8, pp. 2824-2835, 2014.

[45] C. J. Brinker and G. W. Scherer, Sol-Gel Science, Academic Press, San Diego, Calif, USA, 1990.

[46] C. C. Torres, J. B. Alderete, G. Pecchi et al., "Heterogeneous hydrogenation of nitroaromatic compounds on gold catalysts: influence of titanium substitution in MCM-41 mesoporous supports," Applied Catalysis A: General, vol. 517, pp. 110-119, 2016.

[47] S. Deki, Y. Aoi, H. Yanagimoto et al., "Preparation and characterization of $\mathrm{Au}$-dispersed $\mathrm{TiO}_{2}$ thin films by a liquid-phase deposition method," Journal of Materials Chemistry, vol. 6, no. 12, pp. 1879-1882, 1996.

[48] F. Cárdenas-Lizana, S. Gómez-Quero, and M. A. Keane, "Exclusive production of chloroaniline from chloronitrobenzene over $\mathrm{Au} / \mathrm{TiO}_{2}$ and $\mathrm{Au} / \mathrm{Al}_{2} \mathrm{O}_{3}$," ChemSusChem, vol. 1, no. 3, pp. 215221, 2008.

[49] H. Deng, Y. Xu, Q. Chen, X. Wei, and B. Zhu, "High flux positively charged nanofiltration membranes prepared by UVinitiated graft polymerization of methacrylatoethyl trimethyl ammonium chloride (DMC) onto polysulfone membranes," Journal of Membrane Science, vol. 366, no. 1-2, pp. 363-372, 2011. 

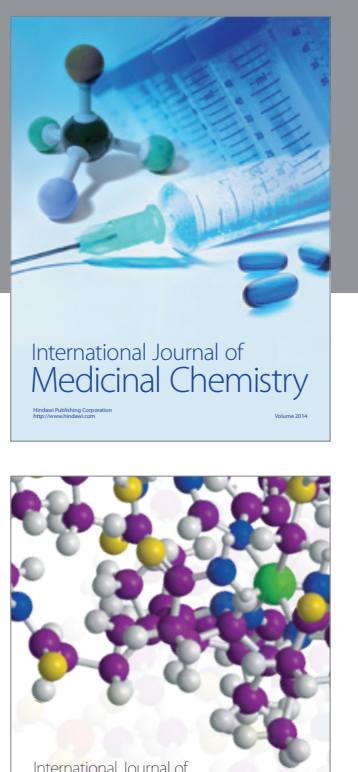

Carbohydrate Chemistry

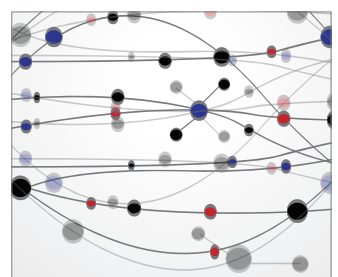

The Scientific World Journal
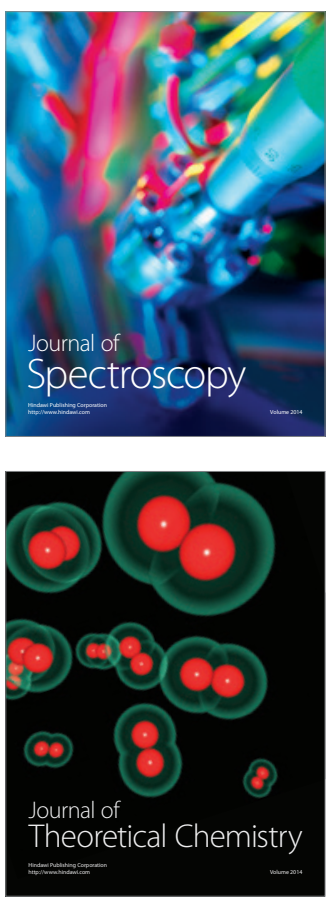
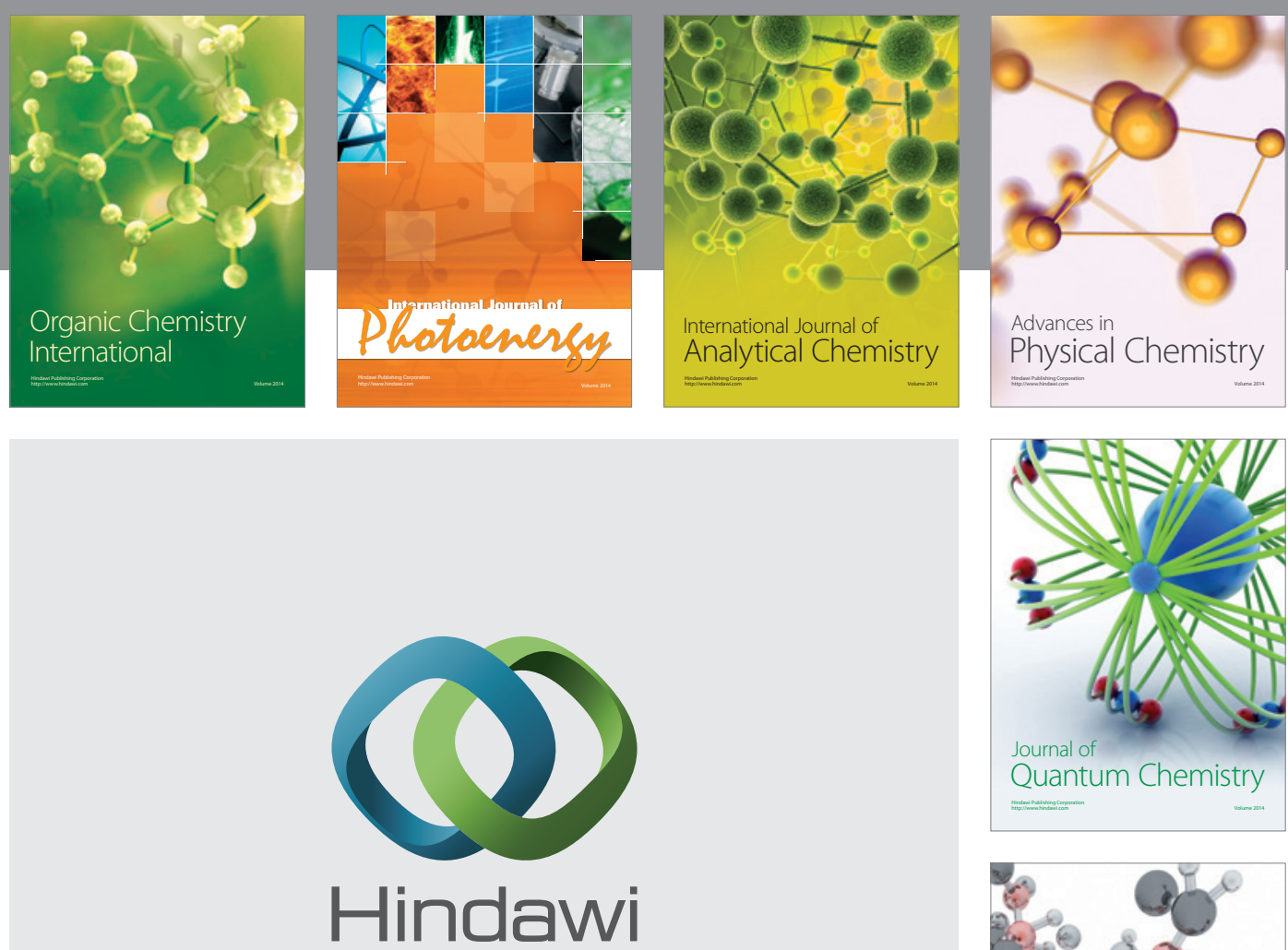

Submit your manuscripts at

https://www.hindawi.com

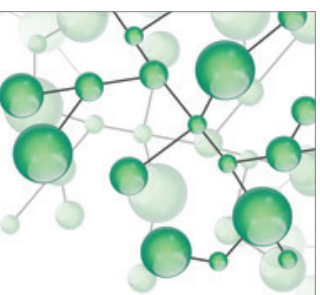

International Journal of

Inorganic Chemistry
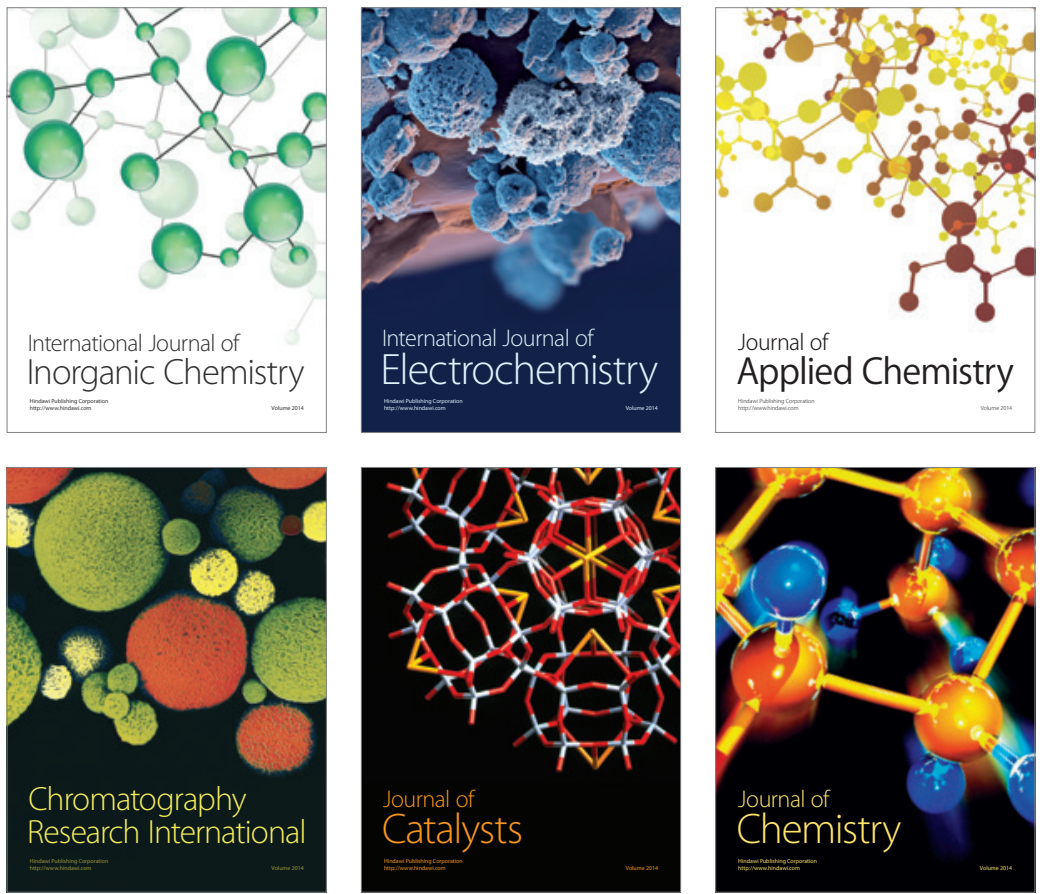

Journal of

Applied Chemistry
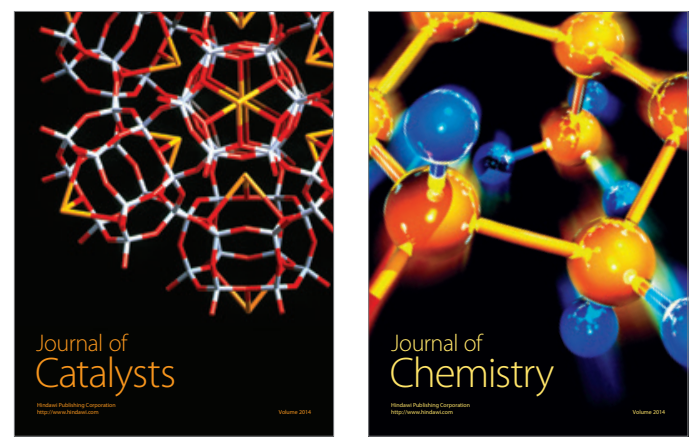
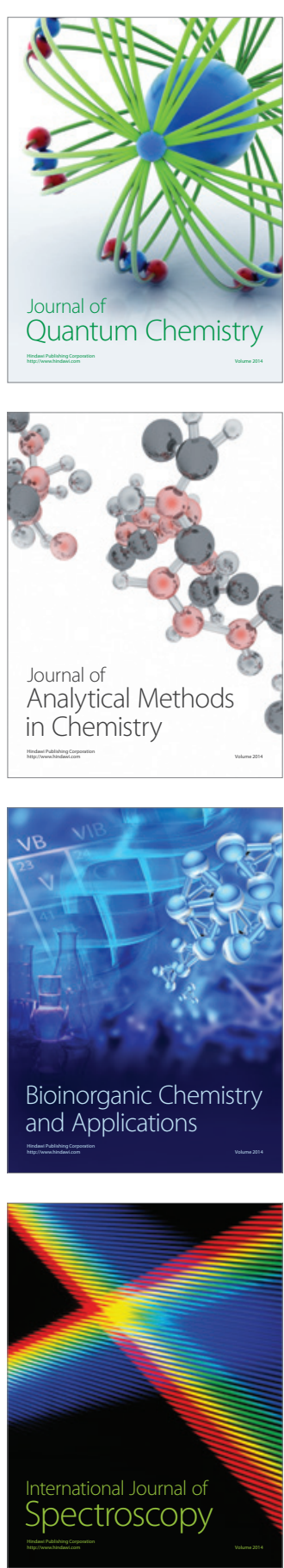